\title{
Desarrollos recientes sobre el consumo global de alcohol y consumos de alto riesgo: argumentos a favor de las intervenciones efectivas a nivel de población en Canadá
}

\section{Recent Developments in Overall Alcohol Consumption and High Risk Drinking: A Case for Effective Population Level Interventions in Canada}

\author{
Norman Giesbrecht \\ Senior Scientist, Social, Prevention and Health Policy Research Department, \\ Centre for Addiction and Mental Health, Toronto, Ontario, Canadá. \\ Enviar correspondencia a: \\ Norman Giesbrecht, Ph.D., Centre for Addiction and Mental Health, 33 Russell St., Toronto, Ontario, Canada M5S 2S1 \\ Phone: (1) 416 535-8501 ext 6895; Fax (1) 416 595-6899; email: Norman_giesbrecht@camh.net
}

\section{RESUMEN}

Cada vez existen más evidencias de las importantes repercusiones del alcohol en forma de enfermedades crónicas, traumas, problemas sociales y elevados costes económicos. En una serie de países se ha producido un aumento del consumo y/o del consumo de alto riesgo en los últimos años. Sin embargo, en muchos contextos la regulación del alcohol aún no es de alta prioridad. Canadá ha experimentado diversas circunstancias en años recientes: el aumento gradual del consumo global, el aumento del consumo de alto riesgo, comercialización y promoción amplia de las bebidas alcohólicas y mayor facilidad para acceder al alcohol. Los datos de las investigaciones realizadas en Canadá y en Ontario, la provincia más poblada, indican que la proporción de los que consumen más de 5 bebidas en una sola ocasión ha aumentado desde mediados de los años noventa. En conjunto, y calculando por lo bajo, se estima que el daño provocado por el alcohol ha supuesto catorce mil millones de dólares canadienses en costes sociales, según datos de 2002. Existe una estrategia nacional frente al alcohol y varias de ámbito provincial diseñadas para reducir los problemas provocados por el alcohol, pero de momento son meras propuestas y no se han puesto en práctica a fondo. Para crear iniciativas efectivas, eficientes y decisivas y reducir el daño global se destacan una serie de recomendaciones: aumento de los precios/impuestos del alcohol, limitación del acceso al mismo a través del control de la densidad de puntos de venta y de las horas de apertura, renovación de las funciones de control de las juntas de bebidas alcohólicas, y disposición de recursos para ejecutar estas medidas de forma efectiva.

Palabras clave: daño provocado por el alcohol, políticas, alcohol, tendencias de consumo, pautas de consumo de alcohol.

\section{ABSTRACT}

There is growing evidence of extensive damage from alcohol to chronic disease, trauma, social problems and high economic costs. In a number of countries there has been an increase in consumption and/or high risk drinking in recent years. However, it appears that in many context alcohol management is not yet of high priority. Canada has experienced several developments in recent years: a gradual increase in overall consumption, an increase in high risk drinking, more extensive marketing and promotion of alcoholic beverages, and easier access to alcohol. Survey data for Canada, and for Ontario, the most populous province, indicate that the proportion drinking $5+$ per occasion has increased since the mid-1990s. Overall, alcoholrelated harm has been conservatively estimated to contribute to $\$ 14$ billion to social costs using 2002 Canadian data. There are a national and several provincial-level alcohol strategies designed to reducing alcohol-related problems, but they are at the proposal, not full-scale implementation, stage. In order to generate effective, efficient and decisive action and reduce overall harm, several recommendations are highlighted: an increase in alcohol pricing/taxation, a ceiling on further access via controls on outlet density and hours of sale, a rejuvenation of the control functions of liquor boards, and the resources to effectively implementation these measures.

Key words: alcohol-related harm, population level alcohol policies, trends in consumption, drinking patterns. 
E nuchas sociedades la respuesta a los asuntos relacionados con el alcohol se puede describir como desconcertante $\mathrm{O}$, de forma más cándida, como incoherente, descuidada e incluso ambigua. Cada vez existen más pruebas de las importantes repercusiones del alcohol en forma de enfermedades crónicas, traumas, problemas sociales y elevados costes económicos (Edwards, Anderson, Babor, Casswell, Ferrence, Giesbrecht et al. 1994; Babor, Caetano, Casswell, Edwards, Giesbrecht, Graham et al, 2003; Rehm, Baliunas, Brochu, Fischer, Gnam, Patra et al., 2006a). Estos impactos negativos no sólo afectan al bebedor crónico a gran escala, al bebedor impulsivo que sufre daños o muerte debido a la intoxicación accidental por alcohol o a los que sufren traumas por conducir bajo los efectos del alcohol. El alcohol no se asocia únicamente con problemas sociales y traumáticos, sino con una amplia gama de enfermedades crónicas (Rehm, Room, Monteiro, Graham, Rehn, Tempos y Jernigan, 2003), entre ellas varios tipos de cáncer (Baan, Straif, Grosse, Secretan, El Ghassassi, Bouvard, et al., 2007; Marmot, 2007). Todos los sectores y grupos de edad de la sociedad experimentan los perjuicios provocados por el alcohol. El «daño colateral» no se limita a los bebedores a gran escala, sino que incluye a víctimas inocentes, como los pasajeros en los accidentes de tráfico, las víctimas de reyertas suscitadas por el alcohol, y los cónyuges e hijos cuando el alcohol contribuye a la violencia doméstica.

Sobre una base global el alcohol ocupa el quinto lugar en cuanto a contribución a años de vida perdidos por incapacidad (DALYs), y en los países en vías de desarrollo con baja mortalidad ocupa el primer lugar $(6,2 \%$ de DALYs), por delante del tabaco y de la tensión arterial (WHO, 2002). Una serie de países han experimentado un incremento del consumo y/o del consumo de alcohol de alto riesgo en años recientes, entre ellos España (WHO, 2004d), Rusia (WHO, 2004c) y Reino Unido (British Medical Association Board of Science, 2008), por no citar más que unos pocos. En el Reino Unido estos hechos se relacionan con un política gubernamental sobre el alcohol muy deficiente que, por defecto, ha contribuido a promover el daño en vez de reducirlo (Heather, 2006; Anderson, 2007; Leon y McCambridge, 2007; Plant y Plant, 2007).

Hay que reconocer el mérito de Italia (WHO 2004b) y de Francia (2004c), que han experimentado un descenso en el consumo total en las últimas décadas. La experiencia italiana no se asocia con campañas de prevención específicas ni con estrategias de control, sino con tendencias seculares graduales a largo plazo entre las que se cuentan: migraciones internas a centros urbanos, cambios en la organización del trabajo, políticas agrícolas, precios del alcohol y mayor toma de conciencia acerca de las consecuencias del consumo excesivo de alcohol (Allamani y Prina, 2007). En n many societies the response to alcohol issues can politely be described as puzzling, and more candidly as inconsistent, careless or even duplicitous. There is growing evidence of the extensive damage from alcohol to chronic disease, trauma, social problems and high economic costs (Edwards, Anderson, Babor, Casswell, Ferrence, Giesbrecht et al. 1994; Babor, Caetano \& Casswell, 2003; Rehm, Baliunas, Brochu, Fischer, Gnam, Patra et al., 2006a). These negative impacts involve not only the chronic heavy drinker, the impulsive drinker who is damaged or killed due to accidental poisoning from alcohol, or those who experience trauma due to their drinking and driving. Not only is alcohol linked with trauma and social problems, but with a wide range of chronic disease (Rehm, Room, Monteiro, Graham, Rehn, Tempos \& Jernigan, 2003) including several types of cancer (Baan, Straif, Grosse, Secretan, El Ghassassi, Bouvard et al., 2007; Marmot, 2007). All sectors of society and age groups are impacted by alcohol-related harm. The 'collateral damage' is not restricted to fellow heavy drinkers, but also includes innocent victims, such as passengers in automobile crashes, victims of brawls fueled by alcohol, and partners and children when alcohol contributes to domestic violence.

On a global basis alcohol is ranked fifth in its contribution to disability adjusted life years (DALYs), and in low mortality developing countries it ranks first $(6.2 \%$ of DALYs) ahead of tobacco and blood pressure (WHO, 2002). A number of countries have experienced an increase in consumption and/ or high risk drinking in recent years, including Spain (WHO, 2004d), Russia (WHO, 2004c) and the United Kingdom (British Medical Association Board of Science, 2008), to mention a few. In the United Kingdom these developments appeared to be related to seriously flawed government alcohol policy that has by default contributed to harm promotion rather than harm reduction (Heather, 2006; Anderson, 2007; Leon \& McCambridge, 2007; Plant \& Plant, 2007).

To their credit Italy (WHO 2004b) and France (2004c) have experienced a decline in overall consumption in recent decades. The Italian experience is apparently not mainly linked to a specific prevention campaign or control strategy but to long-term gradual secular trends involving: internal migration to urban centres, changes in the organization of work, agricultural policies, prices of alcohol and increased awareness of the consequences of excessive consumption (Allamani \& Prina, 2007). In France intensive alcohol control and harm reduction campaign from the early 1990s (INPES; MILDT, 2007) appears to have reinforced this decline and also produced greater awareness of alcohol issues. 
Francia el control intensivo del alcohol y las campañas de reducción de daños desde principios de los años noventa (INPES; MILDT, 2007) han propiciado el descenso y generado mayor sensibilidad ante el alcohol.

En semejantes circunstancias —altas tasas de daño y costes, impacto sobre todos los sectores de la sociedad, tendencias crecientes al consumo de alto riesgo, por citar sólo unas cuantas - ¿no sería razonable esperar que los gobiernos y las organizaciones no gubernamentales considerasen la situación crítica? Sin embargo, no ocurre así en algunas jurisdicciones. El alcohol no es una prioridad inmediata $y$, en muchos casos, incluso en contextos de salud pública, resulta atrevido sacar el tema a relucir (Giesbrecht, Haydon, Kobus-Matthews, Rehm y Roerecke, 2006a). Las respuestas no suelen ser las más efectivas (Giesbrecht 2007), tampoco tienen gran alcance ni son de larga duración. En el contexto más amplio de la salud pública comunitaria al alcohol se le concede un estatus tangencial o ni siquiera se considera un tema de salud pública, centrándose principalmente en los beneficios sanitarios (CDPAC), que en realidad se limitan a una minoría -bebedores de mediana edad y mayores que beben escasas cantidades (Anderson, 2005).

En resumen, en muchas jurisdicciones no hacer nada o poner en práctica sólo medidas sin suficiente eficacia provoca el aumento de los daños por defecto. Tal vez tengan que empeorar aún más las cosas para que haya una visibilidad suficiente de los problemas del alcohol (British Medical Association Board of Science, 2008) y se implanten políticas efectivas contra el alcohol (Heather, 2006). Sin embargo, hay un enfoque que seguramente reduciría el daño provocado por el alcohol. Involucra a muchos sectores de la sociedad, no sólo a los especialistas en el tema del alcohol, sino a los gobiernos que no temen al estamento comercial, y exige un nivel de dinamismo y de acción comparable al que se adopta en otros asuntos sanitarios, como el del control del tabaco o el de las dietas insanas (Daynard, 2004; García, 2007). A continuación se ofrecen las experiencias y avances recientes de Canadá, confiando en que haya lecciones comunes o temas genéricos de utilidad para otras comunidades.

\section{REGULACIÓN DEL ALCOHOL}

En Canadá la mayoría de las potestades de regulación del alcohol corresponden a los gobiernos provinciales o territoriales. Los municipios pueden promulgar leyes especiales, pero sistemáticamente se desobedecen cuando son más restrictivas que las de la provincia en la que se ubican. En Canadá el sistema actual de control y venta de alcohol engloba una combinación de iniciativas privadas y públicas (Giesbrecht y $\mathrm{Ba}$, 2006). En todas las provincias existe control guberna-
Given these circumstances - high rates of damage and costs, impact on all sectors of society, growing trends in high risk drinking - is it not reasonable to expect that governments and NGOs would be in crisis mode with regard to this issue? This is not the case in some jurisdictions. Alcohol is not a high priority, and in many contexts, even public health settings, it is challenging to make the case that it should be (Giesbrecht, Haydon, Kobus-Matthews, Rehm \& Roerecke, 2006a). The responses tend not to be the most effective ones (Giesbrecht, 2007), or those of wide scope and long-term impact. In the broader public health community, alcohol may be given tangential status or even belittled as a public health issue by focusing mainly on health benefits (CDPAC), which are actually restricted to a minority --- middleaged and older drinkers who drink small amounts (Anderson, 2005).

In short, in many jurisdictions, by doing nothing, or doing only what is largely impotent, results in harm promotion by default. It may indeed be that things will have to get worse before there is sufficient visibility of alcohol problems and concern (British Medical Association Board of Science, 2008), to implement effective alcohol policies (Heather, 2006). However, there is a way forward that will likely reduce alcoholrelated harm. It will involve many sectors of society -not only alcohol specialists, governments that are not intimidated by the commercial sector, and a level of advocacy and action that is comparable to that taken on other health issues, such as tobacco control and unhealthy diet (Daynard, 2004; Garcia, 2007). The following discussion draw on recent experiences and developments in Canada, and it is expected that there are some common generic lessons or themes for other communities.

\section{ALCOHOL MANAGEMENT}

Most of the powers for alcohol management reside with the provincial or territorial governments of Canada. Municipalities can enact special laws but they are typically thwarted if they are more restrictive than those of the host province. In Canada the current system of alcohol control and retailing involves a combination of private and public sector initiatives (Giesbrecht \& Ba, 2006). All provinces have some form of government control whether it be at the wholesale, retail, or combination of measures (Room, Stoduto, Demers, Ogborne y Giesbrecht, 2006). In all jurisdictions, except Alberta, at least some of the retail outlets are operated by the provincial or territorial 
mental; bien sea en la venta al por mayor, en la venta al por menor o en ambas (Room, Stoduto, Demers, Ogborne y Giesbrecht, 2006). En todas las jurisdicciones, salvo en Alberta, los gobiernos provinciales o territoriales gestionan determinados puntos de venta al por menor. Este sistema mixto se puede considerar "privatización solapada», pues incluso las redes gubernamentales de venta al por menor son cada vez más agresivas, sofisticadas y dedican más fondos a la publicidad y promoción de los productos alcohólicos. En parte, el esfuerzo publicitario pretende evitar las amenazas de privatización (p. e. Giesbrecht, Stoduto y Kavanaugh, 2006b), pero al mismo tiempo lo potencia el abandono de las funciones de control por parte de los vendedores minoristas gubernamentales. Estos se limitan fundamentalmente a dos dimensiones: proporcionar carteles o mensajes de advertencia sobre ciertos peligros asociados con el consumo de alto riesgo y rechazar a los clientes con signos de embriaguez o que no tienen edad para beber (19 años en la mayoría de las provincias, salvo en tres -Alberta, Manitoba y Quebec-, que es de 18).

- Las instrucciones actuales de las juntas y comisiones gubernamentales de bebidas alcohólicas no incluyen los siguientes puntos:

- Preocupación por el incremento de la tasa global de consumo e iniciativas para invertir la tendencia.

- Iniciativas para que los precios de venta al por menor se equiparen al coste de la vida.

- Limitación de la densidad de puntos de venta y mantenimiento del statu quo en los horarios de venta.

- Estrategias efectivas para controlar el consumo de alto riesgo.

En otras palabras, las intervenciones que han demostrado una eficacia especial en el control del consumo de alto riesgo y en la reducción del daño provocado por el alcohol (Babor et al., 2003) no son prioritarias para las agencias y comisiones gubernamentales de bebidas alcohólicas. Peor aún, ocurre todo lo contrario; se aplaude el incremento anual de ventas como prueba fehaciente de la eficacia de los sistemas de venta de alcohol al por menor, incluyendo el papel esencial que juegan en él los minoristas gubernamentales (p. e, Liquor Control Board of Ontario, 2003).

\section{TENDENCIASY PAUTAS RECIENTES}

Por tanto, no sorprende a nadie que últimamente haya graves motivos de preocupación. Desde mediados de los años noventa se ha producido un aumento gradual del consumo global que en fechas recientes se cifra en aproximadamente 7,9 litros por persona de más de 15 años (Statistics Canada 2002, 2005 b). governments. This mixed system may be labelled as 'privatization by stealth' as even the governmental alcohol retailing networks have become increasingly aggressive, sophisticated and well financed in marketing and promotion of alcohol products. In part, this emphasis on marketing is to stave off threats of privatization (e. g. Giesbrecht, Stoduto y Kavanaugh, 2006 b), but it is also stimulated by the parallel shift among government retailers away control functions. These are now limited primarily to two dimensions: providing warning posters or messages about some the dangers associated with high risk drinking, and challenging customers who appear to be intoxicated or under the legal drinking age - which is 19 in most provinces, and 18 in three (Alberta, Manitoba and Quebec).

- It appears that the current mandates of the government liquor boards and commissions do not include any the following:

- a concern about an increase in the overall rate of consumption and efforts to reverse the trend;

- initiatives to have retail prices keep pace with the cost of living; a ceiling on density of outlets;

- maintainence of the status quo on hours of sale; or effective strategies to control high-risk drinking.

In other words, those interventions that have been shown to particularly effective in controlling high risk drinking and reducing the damage from alcohol (Babor et al., 203), are not central to the mandate of government liquor agencies and commissions. Indeed, just the opposite is true -- an increase in annual alcohol sales is applauded as yet further evidence of the effectiveness of the alcohol retail systems, including the central role played by government retailers (e.g., Liquor Control Board of Ontario, 2003).

\section{RECENT TRENDS AND PATTERNS}

Therefore it should come as no surprise that the several recent developments are cause for concern. Since about the mid-1990s there has been a gradual increase in overall consumption which is recently about 7.9 liters per person aged 15 and older (Statistics Canada 2002, 2005b). There has also been an increase in high risk drinking during the same time (Statistics Canada, 1997, 1999, 2003, 2005a)-- defined as those who consume five or more drinks on an occasion.

National surveys show the following patterns. Almost $80 \%$ of adults (those aged 15 and older) consumed alcohol in the past 12 months. About 23\% of current drinkers exceeded the low risk drinking 
También se ha registrado un aumento del consumo de alto riesgo en el mismo período (Statistics Canada 1997, 1999, 2003, 2005a), englobando en dicho concepto a los que consumen cinco o más bebidas en una sola ocasión.

Los estudios nacionales muestran las siguientes tendencias: casi el 80\% de los adultos (personas de más de 15 años) consumieron alcohol en los últimos doce meses. Aproximadamente el $23 \%$ de los bebedores sobrepasaron las pautas de consumo de bajo riesgo $(\mathrm{CAMH}, \text { s.f. })^{*}$, y el $17 \%$ se incluyeron en la categoría de bebedores peligrosos del AUDIT (prueba de identificación del consumo patológico de alcohol). Aproximadamente el 33\% reconocieron haber sufrido algún perjuicio u otros problemas en el último año debido al consumo del alcohol por parte de otras personas. También llama la atención que el consumo de alto riesgo se produzca principalmente entre personas jóvenes, de edades comprendidas entre 15 y 24 años, más que entre personas que superan los 45 años, y sobre todo entre hombres (CCSA, 2004, Adlaf, Begin y Sawka, 2005; Demers y Poulin, 2005).

En Ontario, la provincia más poblada, se registran unas interesantes tendencias paralelas. Durante cierto tiempo bajaron las ventas globales (según las estadísticas oficiales, Statistics Canada 2002), y el número medio de bebidas por semana descendió de 4,7 a 3,3 entre 1992 y 1996 (Adlaf, lalomiteanu y Rehm, 2008). Las ventas globales comenzaron a aumentar en Ontario (y en todo Canadá) en 1997. Entre 1997 y 2005 el número medio de bebidas semanales — según datos de estudio-, aumentó de 3,4 a 3,8, sin que hubiese una diferencia global significativa. Sin embargo, se produjo un aumento significativo entre las mujeres, de 1,9 bebidas de media a la semana en 1996 a 2,6 en 2005, así como aumentos importantes entre el grupo de edad comprendido entre 40 y 45 años y entre los que no habían concluido la educación secundaria (Adlaf, lalomiteanu y Rehm, 2008). Tal vez parezca que unas cuantas bebidas a la semana no tienen consecuencias, pero este promedio se basa en un amplio espectro, desde los que sólo consumen unas cuantas bebidas al año o los que toman varias o muchas al día.

Existen otras evidencias de Ontario, la provincia más poblada, que indican un reciente aumento del consumo de alcohol de alto riesgo. En 2005 el 25\% de los ontarienses (32\% de bebedores) de más de 18 años reconocieron haber superado las pautas de con- guidelines (CAMH, n.d.)*, and $17 \%$ were scored as hazardous drinkers on the AUDIT scale. Also, about $33 \%$ said that they had experienced some harm or other problems in the past year, due to drinking by others. It is also note-worthy that high risk drinking is more common among younger persons, e.g. aged 15-24, than among those over 45, and particularly among males (CCSA, 2004, Adlaf, Begin \& Sawka, 2005; Demers \& Poulin, 2005).

In Ontario, the most populous province, there have been some interesting parallel trends. During a time when overall sales where declining (based on official statistics) (Statistics Canada 2002), the average number of drinks per week as reported in surveys decreased from 4.7 to 3.3. between 1992 and 1996 (Adlaf, lalomiteanu \& Rehm, 2008). Overall sales in Ontario (and also for Canada) began to increase in 1997. Between 1997 and 2005 the average number of drinks per week - based on survey data -- increased from 3.4 to 3.8 , the overall difference was not significant. However there was a significant increase among women from 1.9 average drinks per week in 1996 to 2.6 in 2005, as well as significant increases among 40-45 year olds, and among those with less than high school education (Adlaf, lalomiteanu \& Rehm, 2008). Now it may seem that a few drinks a week is of no consequence, but this average is based on a wide range, including those who have only a few drinks a year to those who drink several or more drinks a day.

There is further evidence from Ontario that points to a recent increase in high risk drinking. In 2005, 25\% of Ontarians (32\% of drinkers) aged 18 and older, reported exceeding the $L R D G$. The rate was higher among men than women (34\% to $17 \%)$, and highest among those aged 18-29 (38\%) and lowest among those 65 years and older (12\%). Between 2003 and 2005 the percent of Ontarians exceeding the LRDG has increased significantly from $21 \%$ to $25 \%$ (Adlaf et al., 2008).

There are also troubling developments with regard to prevalence of heavy drinking episodes, defined as consuming 5 or more drinks on a single occasion. In $200530 \%$ of Ontarians reported monthly heavy drinking and $11 \%$ reported this on a weekly basis. Finally, long-term trends in this pattern illustrate that

* En Ontario se estiman en un máximo de dos bebidas estándar al día, y de 14 a la semana para los hombres y 9 a la semana para las mujeres. Una bebida estándar contiene aproximadamente 13,6 gramos de etanol. En la actualidad se están revisando las pautas de consumo de alcohol de bajo riesgo.

* In Ontario these are defined as no more than 2 standard drinks a day, and a maximum per week of 14 for men and 9 for women. A standard drink is approximately 13.6 grams of ethanol. National low risk drinking guidelines are currently under development. 
sumo de bajo riesgo. La tasa fue mayor entre los hombres que entre las mujeres (34\% frente a 17\%), más alta entre el grupo de edad de 18 a 29 años (38\%) y más baja entre los mayores de 65 años (12\%). Entre 2003 y 2005 el porcentaje de ontarienses que superó las pautas de consumo de bajo riesgo aumentó significativamente del $21 \%$ al $25 \%$ (Adlaf, lalomiteanu y Rehm, 2008).

Se han registrado también hechos preocupantes con respecto a la prevalencia de episodios de consumo excesivo de alcohol, definidos como el consumo de cinco o más bebidas en una sola ocasión. En 2005 el $30 \%$ de los ontarienses reconocieron haber consumido alcohol en exceso mensualmente y el $11 \%$ semanalmente. Por último, las tendencias de este modelo a largo plazo indican que el consumo excesivo semanal se mantuvo entre el $7 \%$ y el $8 \%$ desde 1977 a 1995. Sin embargo, en 1996 ascendió al 12\% y permaneció en ese nivel: en 2005 fue del 11\%. El incremento de 1996 se notó de forma especial entre los hombres, pasando del $11 \%$ al $19 \%$ en un año, y entre el grupo de edad de 18 a 29 años, pasando del $11 \%$ al $21 \%$ entre 1995 y 1996 (Adlaf, lalomiteanu y Rehm, 2008).

Aún no se han encontrado explicaciones para estos cambios en las pautas de consumo de alcohol en 1996. Sin embargo, se observa que las ventas globales aumentaron en esa época (Statistics Canada 2002, 2005b). Simultáneamente, hubo un intenso debate sobre la propuesta de privatización de los puntos de venta de alcohol gubernamentales en Ontario (Giesbrecht, Stoduto y Kavanagh 2006b), que contribuyó a que los minoristas gubernamentales se esforzasen por demostrar que podían obtener elevadas ventas y beneficios sin ser privatizados (Giesbrecht y MacKenzie, 2000).

\section{Daños y costes derivados del consumo de alcohol}

Hay pruebas de la relación entre las ventas globales de alcohol y las pautas de daños. Los estudios sobre mortalidad entre 1950 y 2000 han demostrado que la tasa general de venta de alcohol en Canadá se relaciona con accidentes de tráfico (Skog, 2000), suicidios (Ramstedt, 2005), homicidios (Rossow, 2004), cirrosis hepática (Ramstedt, 2003), muertes provocadas específicamente por el alcohol (Ramstedt, 2004), y mortalidad total (Norström, 2004).

Análisis recientes han destacado el daño provocado por el alcohol y los costes que conlleva (Canadian Centre on Substance Abuse, 2004; Rehm, Baliunas, Brochu, Fischer, Gnam, Patra et al., 2006a; Rehm, Giesbrecht, Patra y Roerecke, 2006b; Rehm, Patra y Popova, 2006c; Taylor, Rehm, Room, Patra y Bondy, en prensa). Y así por ejemplo, en 2002 se calcularon en 8103 las muertes provocadas por el alcohol, con weekly heavy drinking was at $7 \%$ to $8 \%$ between 1977 to 1995 . However, in 1996 it rose to $12 \%$ and stayed at about that level - e.g., $11 \%$ in 2005 . The increase in 1996 was particularly dramatic among males, going from $11 \%$ to $19 \%$ in one year, and for those aged $18-29$-- from $11 \%$ to $21 \%$ between 1995 and 1996 ((Adlaf et al., 2008).

It is an open question as to what the key explanations might be for these changes in drinking patterns in 1996. However, it is noteworthy that overall sales increased around the same time (Statistics Canada, 2002, 2005b). Concurrently there was significant debate about proposed privatization of government alcohol outlets in Ontario (Giesbrecht, Stoduto \& Kavanagh, 2006b), which likely contributed to more intensive efforts by government agency retailers to demonstrate that they could generate high sales and profits without being privatized (Giesbrecht \& MacKenzie, 2000).

\section{ALCOHOL-RELATED DAMAGE AND COSTS}

There is also evidence of associations between overall sales of alcohol and trends in damage. Studies focusing on mortality between 1950 to about 2000, have shown that overall rate of sales of alcohol in Canada are associated with traffic crashes (Skog, 2003), suicides (Ramstedt, 2005), homicides (Rossow, 2004), liver cirrhosis (Ramstedt, 2003), alcohol specific causes of death (Ramstedt, 2004), and total mortality (Norström. 2004).

Recent analyses have further highlighted damage from alcohol and attendant costs (Canadian Centre on Substance Abuse, 2004; Rehm, Baliunas, Brochu, Fischer, Gnam, Patra et al., 2006a; Rehm Giesbrecht, Patra \& Roerecke, 2006b, Rehm, Patra \& Popova, 2006c; Taylor, Taylor, Rehm, Room, Patra \& Bondy, in press). It is noted, for example, that in 2002 there were an estimated 8,103 deaths attributable to alcohol, and 191, 136 potential years of life lost, and 1, 587,054 acute care hospital days (Rehm et al. 2006a).

Damage associated with alcohol does not come without costs. Using 2002 data, Jürgen Rehm and colleagues (2006b) estimated that social costs of alcohol in Canada was $\$ 14,554.0$ million dollars (or $\$ 14.5$ billion). This included the following break-down (all amounts in millions): direct health care costs - $\$$ 3,306.2; law enforcement costs -- \$3,072.2, direct costs of prevention and research - \$53.0; other direct costs - \$996.1 and indirect costs due to productivity losses -- $\$ 7,127,4$.. This is considered a conservative estimate since it does not include many other social costs associated with alcohol problems such as 
191.136 años de vida potencial perdidos, y 1.587.054 días de asistencia hospitalaria (Rehm et al., 2006a).

El daño derivado del alcohol tiene un coste. Utilizando datos de 2002 Jürgen Rehm y sus colaboradores (2006b) han calculado que los costes sociales del alcohol en Canadá fueron de 14.554 millones de dólares canadienses, desglosados de la siguiente forma (todas las cantidades en millones de dólares): costes de atención sanitaria directa, 3.306 millones; costes legales, 3.072 millones; costes directos de prevención e investigación, 53 millones; otros costes directos, 996 millones; y costes indirectos por pérdida de productividad, 7.127 millones. Se considera un cálculo a la baja, pues no incluye otros muchos costes sociales asociados a los problemas del alcohol, como el impacto en el sistema de servicios sociales, vivienda y otros.

Para resumir, en los últimos doce años una serie de señales indican que los problemas derivados del alcohol tienden a aumentar en Canadá y seguirán haciéndolo si persiste el statu quo de la regulación del alcohol. Entre esas señales cabe citar:

- Aumento de las ventas globales per cápita de alcohol.

- Continuación de la promoción y la publicidad extensiva.

- Continuación de la estrecha exigencia de control de las juntas y comisiones de bebidas alcohólicas.

- Aumento del consumo de alto riesgo.

- Aumento del promedio de consumiciones.

- Aumento de los que beben por encima de las pautas de bajo riesgo.

\section{RESPUESTAS}

Sin embargo, hay indicios - no tan fuertes como las presiones señaladas anteriormente- de que es posible una respuesta más efectiva. A continuación se indican una serie de iniciativas recientes.

Se ha elaborado un documento nacional sobre estrategias frente al alcohol con 43 recomendaciones (Canadian Centre on Substance Abuse, 2007). No obstante, el gobierno no lo ha publicado oficialmente ni es probable que se destinen recursos sustanciales a la implantación de las recomendaciones de forma adecuada.

Hay prometedoras iniciativas en tres provincias: Alberta, Columbia Británica y Nueva Escocia. También existen actividades preliminares para desarrollar estrategias provinciales contra el alcohol en otras jurisdicciones como Saskatchewan y Ontario.

En Alberta (AADAC, 2007) la Comisión contra el Consumo de Alcohol y Drogas de Alberta y la Comi- impact on welfare, housing and other social support systems.

To summarize, during the past 12 years there are a number of signals that alcohol-related problems are likely to increase in Canada - if the status quo of alcohol management persists. These include, at minimum, the following:

- An increase in overall per capita sales of alcohol

- A continuation of extensive promotion and marketing

- A continuation of the narrow mandate of control of liquor boards and commissions

- An increase in high risk drinking

- An increase in average number of drinks

- An increase in those who drink above the low risk drinking guidelines

\section{RESPONSES}

However, there are also some signals -- not yet as strong as the pressures noted above -- that a more effective response is feasible. Several recent initiatives are outlined below.

A national alcohol strategy document was developed with 43 recommendations (Canadian Centre on Substance Abuse, 2007). However it has not been officially released by the national government and it is unlikely that substantial resources have been earmarked to insure that the recommendations will implemented in a timely manner.

There are some promising developments in three provinces: Alberta, British Columbia and Nova Scotia. There are also preliminary activities in developing provincial alcohol policy strategies in others jurisdictions, such as Saskatchewan and Ontario.

In Alberta (AADAC, 2007) a document entitled "Developing an Alberta Alcohol Strategy Background Information" was released in 2007 by the Alberta Alcohol and Drug Abuse Commission and the Alberta Gaming and Liquor Commission. It does not provide a detailed specific strategy but provides the groundwork for one, emphasizing such themes as starting from a common ground, underlying principles and best practices. It concludes with brief remarks about population-based approaches and targeted interventions, noting that effective alcohol strategies include both. Several population-based approaches are noted, including: legislation and regulation to 
sión del Juego y de Bebidas Alcohólicas de Alberta publicaron en 2007 un documento titulado «Desarrollo de una estrategia frente al alcohol en Alberta: información preliminar». No ofrece una estrategia concreta y detallada, pero presenta la base preliminar para elaborarla, subrayando los puntos de partida comunes, los principios y las mejores prácticas. Concluye con breves observaciones sobre enfoques basados en la población y sobre intervenciones dirigidas, aseverando que las estrategias efectivas contra el alcohol incluyen ambos aspectos. Entre los enfoques basados en la población se citan los siguientes: legislación y regulación para controlar la capacidad física y el suministro de alcohol, estrategias de precios y gravámenes, y otras medidas para influir en la demanda, promover el consumo responsable de alcohol y limitar la disponibilidad social del alcohol.

El documento de Nueva Escocia se titula «Cambio de la cultura del consumo de alcohol en Nueva Escocia», y lleva el subtítulo de: "Estrategia para prevenir y reducir la carga del daño provocado por el alcohol en Nueva Escocia» (Departamento de Promoción y Protección sanitaria, 2007). Las recomendaciones se organizan en cinco directrices básicas interrelacionadas: capacidad de la comunidad y promoción de las asociaciones, comunicación y marketing social, fortalecimiento de la prevención, intervención y tratamiento tempranos, política de salud pública e investigación y evaluación. Los objetivos de política sanitaria pública son los más relevantes desde una perspectiva basada en la población en incluyen 14 recomendaciones. Y así por ejemplo, se centran en: establecimiento de un comité asesor multisectorial para políticas sobre el alcohol, iniciativas para reducir el consumo excesivo y la embriaguez pública; vínculos de colaboración con socios a nivel nacional, provincial y otros; revisión de las políticas sobre la disponibilidad del alcohol, el acceso de los menores al mismo, controles de la conducción bajo los efectos del alcohol, el manejo de otros vehículos y similares. En conjunto, hay 55 recomendaciones específicas organizadas en 17 grupos bajo cinco directrices clave.

Una propuesta reciente de Columbia Británica sugirió cambios específicos en los «márgenes de beneficio» de los licores para reducir los daños provocados por el consumo de alcohol (Stockwell, Zhao y Thomas, 2008). Presenta cuatro recomendaciones:

- El ofrecimiento de incentivos a la fabricación, comercialización y venta de productos con bajo contenido de alcohol.

- Medidas para asegurar que no se vendan productos alcohólicos a menos de un dólar por bebida estándar canadiense (aproximadamente 13,6 gramos).

- Equiparación de los precios del alcohol con el coste de la vida. control physical availability or supply of alcohol, pricing strategies and taxation, and other measures to influence demand, promote responsible alcohol use and decrease the social availability of alcohol.

The Nova Scotia document is entitled "Changing the Culture of Alcohol Use in Nova Scotia" with a subtitle: "An Alcohol Strategy to Prevent and Reduce the Burden of Alcohol-Related Harm in Nova Scotia" (Department of Health Promotion and Protection, 2007). The recommendations are organized into five inter-related key directions: community capacity and partnership building, communication and social marketing, strengthening prevention, early intervention and treatment, health public policy and research and evaluation. The healthy public policy objectives are most relevant to a populationbased perspective, including 14 recommendations. These focus on, for example: establishing a multisectoral alcohol policy advisory committee; initiatives to reduce overdrinking and public intoxication, collaborative links with partners at national, provincial and other levels, as well as a review of policies pertaining to availability of alcohol, minors' access to alcohol, controls on impaired driving, operation of other vehicles and others. Overall, there are 55 specific recommendations, organized into 17 groups and under five key directions.

- A recent proposal from British Columbia offered specific changes in liquor "markups" in order to reduce harm from alcohol consumption (Stockwell, Zhao y Thomas, 2008). It provides four recommendations.

- That incentives be provide for the manufacture, marketing and sale of lower alcohol content products.

- Steps be taken to insure that alcoholic products not be sold for less than one dollar for a Canadian standard drink (which is about 13.6 grams)

- That alcohol prices keep pace with the cost of living

- A creation of a "nickel a drinking" harm reduction levy to fund new additional treatment and prevention program.

All four of these initiatives, one at the national level and three at the provincial, might be considered at preliminary phase -- recommendations have been put forward and implementation discussions are underway. As noted earlier, both overall consumption (as reflected by total alcohol sales) and high risk drinking have been increasing in recent years. Furthermore, these two dimensions have been 
- Imposición de una tasa de "cinco centavos por bebida» para subvencionar tratamientos de las nuevas adicciones y programas de prevención.

Estas cuatro iniciativas, una de nivel nacional y tres provinciales, se hallan en fase preliminar: se han presentado las recomendaciones y actualmente se analiza su puesta en práctica. Como se ha dicho anteriormente, tanto el consumo global (reflejado en las ventas totales de alcohol) como el consumo de alto riesgo han aumentado en los últimos años. Y además, esos dos aspectos se asocian a enfermedades crónicas, traumas y problemas sociales provocados por el consumo de alcohol (Edwards et al., 1994; Babor et al, 2003; Rehm et al., 2003). Por tanto, es importante saber qué intervenciones o políticas tienen mayor capacidad para reducir el consumo global, el consumo de alto riesgo, o ambos, como medida previa para amortiguar el daño provocado por el alcohol. Puesto que no existen recursos humanos y financieros ilimitados para ejecutar simultáneamente docenas de recomendaciones, sería prudente, y reflejaría sólidos principios de salud pública, centrarse en los que tienen mayor capacidad para reducir el daño provocado por el alcohol a nivel de población.

Partiendo del análisis de Babor et al. (2003, capítulo 16), varios recursos han demostrado su eficacia con sustancial apoyo investigador y amplio alcance:

Aumento de los impuestos/precios del alcohol.

- Restricciones en la densidad de los puntos de venta.

- Fuertes monopolios de venta minorista de alcohol, con el control del alcohol como principio esencial.

- Programas de intervención y responsabilidad del expendedor.

- Elevación de la edad mínima para comprar alcohol.

- Rebaja de los niveles de concentración de alcohol en sangre para los conductores.

- Tolerancia cero de alcohol en los conductores jóvenes.

- Intervenciones breves para los que beben de forma arriesgada.

En Canadá se han dado importantísimos pasos para controlar la conducción bajo los efectos del alcohol en las últimas décadas (Asbridge, Mann, Smart, Stoduto, Beirness, Lamble y Vingilis, en prensa). Igualmente, ha habido iniciativas ejemplares con respecto a la intervención de los expendedores (Graham, Jelley y Purnell, 2005) y a la promoción de intervenciones breves (Cunningham, Koski-Jännes, Wild y Cordingley, 2002). associated with chronic disease, trauma and social problems related to alcohol use (Edwards et al. 1994; Babor et al., 2003; Rehm, Room, Monteiro et al. 2003). Therefore, a relevant question is which interventions or policies are likely to have the greatest potential for curtailing overall consumption, high risk drinking or both, as a significant step in reducing drinking-related harm. Given that there are not unlimited human or financial resources to concurrently implement dozens of recommendations, it would seem prudent, and reflect sound public health principles, to focus on those that have the greatest potential in reducing alcohol related harm at the population level.

Based on the analysis by Babor et al. (2003, chapter 16) there are several that stand out as having shown to be effective, with substantial breadth of research support and with wide scope:

- increase in alcohol taxes/prices,

- restrictions on outlet density,

- strong alcohol retail monopolies with alcohol control as a central mandate,

- server liability intervention programs,

- a high minimum legal purchase age,

- lower BAC levels for drivers,

- zero tolerance for alcohol for young drivers, and

- brief interventions for those drinking in a high risk manner.

In Canada there have been tremendous strides in controlling drinking and driving over the past few decades (Asbridge, Mann, Smart, Stoduto, Beirness, Lamble \& Vingilis, in press). As well, there are exemplary recent initiatives with regard to server intervention (Graham, Jelley \& Purnell, 2005) and promotion of brief interventions (Cunningham, Koski-Jännes, Wild \& Cordingley, 2002). 


\section{SELECCIÓN}

Las tres primeras iniciativas que hemos apuntado son las que requieren atención especial: los precios, el acceso al alcohol y un sistema fuerte de control del alcohol. En esas áreas el control se ha deteriorado de forma escandalosa. Irónicamente, se trata de las intervenciones que tienen mayor impacto en las ventas $y$ el acceso al alcohol en una amplia gama de contextos $y$, por tanto, su influjo positivo en la salud pública es de gran alcance y potencia. Sin duda puede resultar útil, desde el punto de vista académico, enumerar docenas de recomendaciones; pero cuanto más larga sea la lista, menos probabilidades hay de que se tomen medidas efectivas, eficientes y decisivas.

Para reducir el daño del alcohol a nivel de la población en Canadá, proponemos la siguiente selección de intervenciones de gran impacto (Chaloupka, Grossman y Shaffer, 2002; Babor et al, 2003; Cook, 2007; Livingston, Chikritzhs y Room, 2007) que no figuran en las políticas actualmente en vigor sobre el alcohol en Canadá:

- Incremento del precio real de las bebidas alcohólicas e interrupción de los descuentos y los saldos.

- Limitación y statu quo para otros tipos de acceso al alcohol: horas y días de venta, densidad de los puntos de venta de alcohol con consumo dentro y/o fuera del local.

- Renovación de la función de control de las juntas y comisiones de bebidas alcohólicas, incluyendo la reducción de la comercialización y promoción del alcohol.

- Aprovechamiento de los recursos existentes para ejecutar de forma efectiva estas medidas y otras intervenciones eficaces (como se ha apuntado anteriormente).

Es posible que los problemas relacionados con el alcohol no aumenten en años venideros en Canadá. Sin embargo, para ello será necesario que la prevención y las iniciativas de control actuales sean más efectivas y de mayor amplitud en su alcance, y reviste cierta urgencia la ejecución de medidas basadas en la población.

Una cosa es elaborar una selección de recomendaciones y otra muy distinta conseguir el apoyo de los gobiernos, las organizaciones no gubernamentales y el público en general y construir la infraestructura y capacidad necesarias para sostenerlas (Giesbrecht et al., 2006c). Pero se trata de un tema para otro estudio.

\section{A SHORT LIST}

However, it is the first three, noted above, that require special attention - pricing, access to alcohol and a strong alcohol control system. It is in these areas where the controls have been eroded. Ironical$l y$, it is these interventions that have a clear potential to impact most purchases and access to alcohol in a wide range of contexts and thus offer positive public health impacts of wide scope and potency. While there may be some academic utility in laying out dozens of recommendations, the longer the list, the less likely that effective, efficient and decisive action will be taken.

In order to reduce population level damage from alcohol in Canada, the following short list is proposed reflecting high impact interventions (Chaloupka, Grossman \& Saffer, 2002; Babor et al., 2003; Cook, 2007; Livingston, Chikritzhs \& Room, 2007) that currently do not reflect enacted alcohol policies in Canada.

- An increase in the real price of alcoholic beverages and discontination of discount pricing and sale pricing

- A ceiling and status quo on other types of availability - hours and days of sale, density of on-premise and off-premise outlets

- A rejuvenation of the control function of liquor boards and commissions that includes a reduction in alcohol marketing and promotion.

- The resources required to effectively implement these measures and other effective interventions that are already in place (as noted above).

It is feasible that alcohol-related problems will not increase in the coming years in Canada. However, this will likely require that current prevention and control efforts become more effective and broader in their scope of impact, and involve some urgency in implementing several population-based initiatives.

There are a number of challenges in moving from a short list of recommendations to getting the support from governments, NGO and the general public and to build the infra-structure and capacity required to sustain them (e.g. Giesbrecht et al., 2006c). That is a topic for another discussion. 


\section{AGRADECIMIENTOS/ ACKNOWLEDGMENTS}

Este artículo se basa, en parte, en dos ponencias. Una presentada en el 34 Simposio Anual de Epidemiología Alcohólica de la Sociedad Kettil Bruun en Victoria (Columbia Británica) el 5 de junio de 2008, en colaboración con Emma Haydon y Honey Bloomberg. Y la otra presentada en la Conferencia Anual de la Asociación de Asociaciones Locales de Salud Pública en Allison (Ontario) el 9 de junio de 2008. Los datos sobre Ontario ofrecidos en este artículo se basan en análisis de Edward Adlaf, Anca lalomiteanu y Jürgen Rehm. Robert Mann y Svetlana Popova proporcionaron recursos. Los puntos de vista expresados en este documento no reflejan necesariamente las perspectivas o posturas de las organizaciones y personas cuya colaboración se agradece.

\section{REFERENCIAS}

Adlaf, E. M., Begin, P. y Sawka, E. (Eds). (2005). Canadian Addiction Survey (CAS): A national survey of Canadians use of alcohol and other drugs: Prevalence of use and related harms. Detailed report. Ottawa: Canadian Centre on Substance Use.

Adlaf, E. M., lalomiteanu, A. y Rehm, J. (2008). CAMH Monitor eReport: Addiction y Mental Health Indicators Among Ontario Adults, 1977-2005 (CAMH Research Document Series No. 24). Toronto, ON: Centre for Addiction y Mental Health. Disponible en: http://www. camh.net/research/population_life_course.html.

Alberta Alcohol and Drug Abuse Commission y Alberta Gaming and Liquor Commission (2007) Developing an Alberta Alcohol Strategy - Background Information. Alberta Government.

Allamani, A. y Prina, F. (2007). Why the decrease in consumption of alcoholic beverages in Italy between 1970s and the 200s? Shedding light on an Italian mystery. Contemporary Drug Problems, 34 (Summer): 187-297.

Anderson, P. (2005). Alcohol and coronary heart disease. Adicciones, 17: 3-9. Versión en castellano: «El alcohol y las afecciones coronarias".

Anderson, P. (2007). A safe, sensible and social AHRSE: New labour and alcohol policy. Addiction, 102: 1515-1521.

Asbridge, M., Mann, R.E., Smart, R.G., Stoduto, G., Beirness, D., Lamble, R. y Vingilis, E. (en prensa). The effects of Ontario's administrative driver's licence suspension law on total driver fatalities: A multiple time series analysis. Drug, Education, Prevention and Policy.

Baan, R., K. Straif, Y. Grosse, B. Secretan, F. El Ghassassi, V. Bouvard, A. y Altiere, V. Cogliano on behalf of the WHO International Agency for Research on Cancer Monograph Working Group. (2007). Carcinogenicity of Alcoholic Beverages. The Lancet Oncology, 8: 292-293.
This editorial is based, in part, on two presentations. One was at the $34^{\text {th }}$ Kettil Bruun Society's Annual Alcohol Epidemiology Symposium in Victoria, B.C., June 5, 2008, in a paper coauthored by Emma Haydon and Honey Bloomberg. The other was at the Annual Conference of the Association of Local Public Health Associations, Alliston, Ontario, June 9, 2008. The Ontario survey data reported here are based on analysis by Edward Adlaf, Anca lalomiteanu and Jürgen Rehm. Robert Mann and Svetlana Popova provided resource material. The views expressed in this document do not necessarily reflect the perspectives or positions of the organizations or persons acknowledged.

Babor, T., Caetano, R., Casswell, S., Edwards, G., Giesbrecht, N., Graham,K., Grube, J.,Gruenewald, P., Hill, L., Holder, H., Romel, R., Österberg, E., Rehm, J., Room, R. and Rossow, R. (2003). Alcohol, No Ordinary Commodity: Research and Public Policy. Oxford: Oxford University Press.

British Medical Association Board of Science. (2008). Alcohol misuse: tackling the UK epidemic. London: A publication from the BMA Science and Education department of the Board of Science, February, 2008.

Bruun, K., Edwards, G., Lumio,, M., Mäkelä, K., Österbeg, E., Pan, L., Popham, R. E., Schmidt, W., Room, R., Skog, O.-J. (1975). Alcohol Control Policies in Public Health Perspective, Helsinki, Finland: The Finnish Foundation for Alcohol Studies.

Canadian Centre on Substance Abuse. (2004). Alcoholrelated Harms and Control Policy in Canada. http:// www.ccsa.ca/NR/rdonlyres/EF556B91-72B8-4FB5AB3D-ADDD96A9D895/0/ccsa0048402004.pdf

Canadian Centre on Substance Abuse. (2007). Reducing Alcohol-Related Harm in Canda: Toward a Culture of Moderation. Recommendations for a National Alcohol Strategy (April 2007). Alberta Alcohol and Drug Abuse Commission, Canadian Centre on Substance Abuse y Health Canada.

http://www.ccsa.ca/NR/rdonlyres/AB35A74F-2491-4CD08CD7-31F3897BDBBD/0/ccsa0238762007.pdf

Centre for Addiction and Mental Health, Low Risk Drinking Guidelines http://www.camh.net/About_Addiction_ Mental_Health/Drug_and_Addiction_Information/low_ risk_drinking_guidelines.html

Chaloupka. F.J., Grossman, M., y Saffer, H. (2002). The effects of price on alcohol consumption and alcohol-related problems. Alcohol Research and Health, 26(1): 22-34.

Chronic Disease Prevention Alliance of Canada (2008) A Comparative Analysis of National Disease-Specific 
Strategies. (Report prepared by H. Krueger y Associates Inc.).

Cook, P. J. (2007). Paying the tab-- the economics of alcohol policy. Princeton University Press.

Cunningham J.A., Koski-Jännes A., Wild T.C. y Cordingley J. (2002). Treating alcohol problems with self-help materials: A population study. Journal of Studies on Alcohol, 63: 649-654.

Daynard, R.A. (2004). Lessons from tobacco control for the obesity control movement. Journal of Public Health Policy, 24: 291-295.

Demers, A. y Poulin, C. (2005). 3. Alcohol Use. In: Adlaf, E. M., Begin, P. y Sawka, E. (Eds). Canadian Addiction Survey (CAS): A national survey of Canadians use of alcohol and other drugs: Prevalence of use and related harms. Detailed report, pp. 20-32. Ottawa: Canadian Centre on Substance Use.

Department of Health Promotion and Protection Addiction Services, Province of Nova Scotia (2007) Changing the Culture of Alcohol Use in Nova Scotia - An Alcohol Strategy to Prevent and Reduce the Burden of AlcoholRelated Harm in Nova Scotia. Halifax, Province of Nova Scotia.

Edwards, G., Anderson, P., Babor, T. F., Casswell, S., Ferrence, R., Giesbrecht, N., Godfrey, C., Holder, H. D., Lemmens, P., Mäkelä , K., Midanik, L. T., Nörstrom, T., Österberg, E., Romelsjö, A., Room, R., Simpura, J. y Skog, O. J. (1994). Alcohol Policy and the Public Good. Oxford: Oxford University Press.

Garcia, J. (2006). The Ontario Tobacco Strategy: Relevance to Healthy Weights Research, Policy and Practice? Seminar for the Physical Activity and Research Program Public Health Sciences, University of Toronto. (presentación en PowerPoint)

Giesbrecht, N. y MacKenzie, B. (2000) Alcohol retailing by government Liquor Boards in Canada in the 1990s. Report on an International Seminar on Alcohol Retail Monopolies: Exchange of Information and Experience. Helsinki: Alko.

Giesbrecht, N. y Ba, S. (2006) Priorities 2006: Developments in Alcohol Policy since 1996. Toronto: The Alcohol Policy Network and the Ontario Public Health Association.

Giesbrecht, N., Haydon, E., Kobus-Matthews, M., Rehm, J. y Roerecke, M. (2006a) Where is Alcohol in Chronic Disease Prevention Strategies? Epidemiology vs. Prevention Priorities. Annual Meeting of the American Public Health Association, Boston, November 4-8, 2006.

Giesbrecht, N., Stoduto, G. y Kavanagh, L. (2006b) Privatization postponed? Ontario's experience with convergent interests and extensive alcohol marketing. In: Giesbrecht, N., Demers, A., Ogborne, A., Room, R. Stoduto, G. y Lindquist, E. (eds.), Sober Reflections: Commerce, Public Health, and the Evolution of Alcohol Policy in Canada. 1980-2000, pp. 175-200. Montreal, McGill-Queen's University Press.

Giesbrecht, N., Room, R., Demers, A., Lindquist, E., Ogborne, A., Bondy, S., y Stoduto, G. (2006c) Alcohol policies:
Is there a future for public health considerations in a commerce-oriented environment? In: Giesbrecht, N., Demers, A., Ogborne, A., Room, R. Stoduto, G. y Lindquist, E. (eds.), Sober Reflections: Commerce, Public Health, and the Evolution of Alcohol Policy in Canada. 1980-2000, pp. 289-329. Montreal, McGillQueen's University Press.

Giesbrecht, N. (2007) Reducing alcohol-related damage in populations: Rethinking the roles of education and persuasion interventions. Addiction, 101: 1345-1349.

Graham, K., Jelley, J., y Purcell, J.(2005). Training bar staff in preventing and managing aggression in licensed premises, Journal of Substance Use, 10, 48-61.

Heather, N. (2006). Britain's alcohol problem and what the UK government is (and is not) doing about it. Adicciones, 18 (3): 225-235. Versión en castellano : «El problema del alcohol en el Reino Unido y lo que hace (y no hace) el gobierno al respecto".

INPES, Institut National de Prévention et d'Education pour la Santé. INPES website

Leon, D.A., McCambridge, J. (2006). Liver cirrhosis morality rates in Britain, 1950-2002. The Lancet, 367: 9511: 645.

Liquor Control Board of Ontario (2003). LCBO Annual Report 2003-04. Breaking \$1 Billion. Toronto: LCBO Corporate Communication.

Livingston, M., Chikritzhs, T., y Room, R. (2007). Changing the density of alcohol outlets to reduce alcohol-related problems. Drug and Alcohol Review, 26, 557-566.

Marmot, M. (2007). Food, Nutrition, Physical Activity, and the prevention of cancer: A global perspective. Slide presentation on alcohol, based on report by the World Cancer Research Fund and the American Institute for Cancer Research.

MILDT (2007). Toxicomanie MIdLcl. L'alcool et la loi L'alcool est un produit licite. Sa production, sa vente et son usage sont règlementés. Internet site of the Interdepartmental Mission for the Fight against Drugs and Drugs addiction (MILDT) http://www.drogues.gouv. fr/article3061.html

Norström, T. (2004). Per Capita Alcohol Consumption and All-cause Mortality in Canada, 1950-98. Addiction, 99, 1274-1278.

Plant, M.A. y Plant, M.L. (2006). Binge Britain: Alcohol and the National Response. Oxford: Oxford University Press.

Ramstedt, M. (2003). Alcohol Consumption and Liver Cirrhosis Mortality With and Without the Mention of Alcohol - the Case of Canada. Addiction 98, 12671276.

Ramstedt, M. (2004). Alcohol Consumption and Alcoholrelated Mortality in Canada, 1950-2000.Canadian Journal of Public Health 95, 121-126.

Ramstedt, M. (2005) Alcohol and suicide at the population level-the Canadian experience. Drug and Alcohol Review. 24, 203-208.

Rehm, J., Room, R., Monteiro, M., Graham, K., Rehn, N., Sempos, C.T. y Jernigan, D. (2003). Alcohol as a risk 
factor for the global burden of disease. European Addiction Research 9, 157-164

Rehm J., Baliunas, D., Brochu, S., Fischer, B., Gnam, W., Patra, J., Popova, S., Sarnocinska-Hart, A. y Taylor, B. In collaboration with E. Adlaf, M. Recel, E. Single. (2006a). The Costs of Substance Abuse in Canada 2002: Highlights. Ottawa: Canadian Centre on Substance Abuse.

Rehm, J., Giesbrecht, N., Patra, J. y Roerecke, M. (2006b). Estimating chronic disease deaths and hospitalizations due to alcohol use in Canada in 2002 - Implications for policy and prevention strategies. Preventing Chronic Disease, 3 (4). [periódico on line]

Rehm, J., Patra, J. y Popova, S. (2006c). Alcohol-attributable mortality and potential years of life lost in Canada 2001: Implications for prevention and policy. Addiction, 101, 373-384.

Room, R., Stoduto, G., Demers, A. Ogborne, A. y Giesbrecht, N. (2006) Alcohol in the Canadian context. In: Giesbrecht, N., Demers, A., Ogborne, A., Room, R. Stoduto, G. y Lindquist, E. (eds.), Sober Reflections: Commerce, Public Health, and the Evolution of Alcohol Policy in Canada. 1980-2000. pp. 14-42. Montreal, McGill-Queen's University Press.

Rossow, I. (2004). Alcohol consumption and homicides in Canada 1950-1999. Contemporary Drug Problems 31, 541-560.

Skog, O.J. (2003). Alcohol Consumption and Fatal Accidents in Canada, 1950-98. Addiction, 98 (7), 883-893.

Statistics Canada (1997). National Population Health Survey (NPHS): Cycle 1, 1994-95, Vol. Catalogue no. 0019782567-XIB, Ottawa, 1997.

Statistics Canada (1999). National Population Health Survey (NPHS): Cycle 2, 1996-97, Vol. Catalogue no. 0019782 567-XIB, Ottawa, 1999.

Statistics Canada (2002). The Control and Sale of Alcoholic Beverages in Canada, 2001, Vol. Catalogue no.63-202XIB, Ottawa: Minster of Industry, 2002.
Statistics Canada (2003). Canadian Community Health Survey (CCHS), 2001, Vol. Catalogue no.82M0013GPE, Ottawa, 2003.

Statistics Canada (2005a). Canadian Community Health Survey (CCHS), 2003, Vol. Catalogue no.82M0013GPE, Ottawa, 2005a.

Statistics Canada (2005b). The Control and Sale of Alcoholic Beverages in Canada, 2004, Vol. Catalogue no.63-202XIE, Ottawa: Minster of Industry, 2005b.

Stockwell, T., Zhao, J. y Thomas, G. (2008). A proposal to changes in liquor "markups" in British Columbia in order to reduce harm from alcohol consumption. Centre for Addictions Research of B.C. Briefing paper prepare for the Ministry of Finance and Ministry of Public Safety and Solicitor General, Government of British Columbia, January 16, 2008.

Taylor, B., Rehm, J., Room, R., Patra, J. y Bondy, S. (en prensa) Determination of lifetime injury mortality risk in Canada in 2002 by drinking amount per occasion and number of occasions. American Journal of Epidemiology.

World Health Organization (2002). World Health Report: Reducing Risks, Promoting Healthy Life. Geneva: World Health Organization

World Health Organization (2004a). WHO Global Status Report on Alcohol, 2004. Country Profiles, European Region, France. Geneva: World Health Organization.

World Health Organization (2004b). WHO Global Status Report on Alcohol, 2004. Country Profiles, European Region, Italy. Geneva: World Health Organization.

World Health Organization (2004c). WHO Global Status Report on Alcohol, 2004. Country Profiles, European Region, The Russian Federation. Geneva: World Health Organization.

World Health Organization (2004d). WHO Global Status Report on Alcohol, 2004. Country Profiles, European Region, Spain. Geneva: World Health Organization. 
